\title{
Arthropathy, ankylosing spondylitis, and clubbing of fingers in ulcerative colitis
}

K. N. JALAN, R. J. PRESCOTT, R. J. WALKER, W. SIRCUS ${ }^{1}$, J. P. A. McMANUS, AND W. I. CARD

From the Gastro-Intestinal Unit, Western General Hospital, Edinburgh, the Computer and Statistics Section, Department of Social Medicine, University of Edinburgh, and the Department of Medicine in Relation to Mathematics and Computing, University of Glasgow
SUMMARY In a retrospective study of 399 patients with ulcerative colitis, 27 patients had colitic arthritis, 17 had ankylosing spondylitis, and 20 had clubbing of the fingers. Colitic arthritis and ankylosing spondylitis were not related to severity, extent of involvement, or duration of colitis. A significant association between colitic arthropathy and other complications of ulcerative colitis, such as pseudopolyposis, perianal disease, eye lesions, skin eruptions, aphthous ulceration, and liver disease has been demonstrated. The outcome of the first referred attack of colitis in the presence of colitic arthritis and ankylosing spondylitis remained uninfluenced. Clubbing of fingers was related to severity, extent of involvement, and length of the history of colitis. A significant association between clubbing of the fingers and carcinoma of the colon, pseudopolyposis, toxic dilatation, and arthropathy has been shown. The frequency of surgical intervention in patients with clubbing was higher but the overall mortality was not significantly different from the patients without clubbing.

Arthritis (Bargen, 1929; Hench, Baner, Boland, Dawson, Freyberg, Holbrook, Key, Lockie, and McEwen, 1941), ankylosing spondylitis (Fernandez-Herlihy, 1959; Acheson, 1960), and clubbing of fingers (Schlicke and Bargen, 1940; Mendlowitz, 1941; Honska, Strenge, and Hammarsten, 1957) are associated with, and may complicate, the course of ulcerative colitis. In recent reports the clinical, radiological, and serological characters of the arthritis of ulcerative colitis have been shown to differ from rheumatoid arthritis (Bywaters and Ansell, 1958; Wright and Watkinson, 1959; FernandezHerlihy, 1959; McEwen, Lingg, Kirsner, and Spencer, 1962). It is well recognized that there is an increased incidence of ankylosing spondylitis in patients with ulcerative colitis, and a familial predisposition to the development of ankylosing spondylitis alone or in combination with ulcerative colitis or Crohn's disease has been described (McBride, King, Baikie, Crean, and Sircus, 1963). Clubbing of the fingers may be associated with Received for publication 20 March 1970.

'Member of external scientific staff, Medical Research Council. various gastrointestinal diseases, including regional enteritis, bacillary dysentery, amoebic dysentery, sprue, coeliac disease, and ulcerative colitis. The relationship of clubbing of fingers to the extent of bowel involvement has been demonstrated (Young, 1966).

In this communication the characteristics of a population of people with ulcerative colitis with associated arthropathy, ankylosing spondylitis, and clubbing of the fingers are described. For this purpose, comparisons have been made with a control group of patients with ulcerative colitis without these features. The clinical significance, in terms of the outcome of the ulcerative colitis and the relationship to other local and systemic complications, has been examined.

\section{Material and Methods}

The material presented here is part of a large retrospective study of 399 patients with ulcerative colitis seen at the Gastro-Intestinal Unit, 
Western General Hospital, Edinburgh, during the period 1950-1967 inclusive (Jalan, Prescott, Sircus, Card, McManus, Falconer, Small, and Smith, 1970). The primary source of the data was the case records. The information from these case records was transferred to a transcription sheet and then to punch cards and analysed with the aid of an ATLAS computer.

\section{Criteria for Diagnosis of Ulcerative Colitis}

In the majority of patients a firm diagnosis of ulcerative colitis was made during life. In a few patients it was only confirmed at necropsy. The diagnosis required the presence of the following: (1) rectal bleeding with or without diarrhoea; (2) absence of any pathogenic organisms from the stool on culture and on microscopic examination; and (3) sigmoidoscopic appearances of hyperaemia, oedema, granularity and friability, and/or typical radiological appearances.

In patients who died or were treated surgically histological confirmation that the disease was confined to the mucosa and submucosa was obtained. Crohn's disease and ischaemic colitis were excluded using the criteria of Morson (1968).

Transient episodes of asymmetrical monoarticular inflammation, predominantly involving larger joints, occurring either before or during an attack of ulcerative colitis, were taken to be indicative of arthritis. Exclusion of rheumatoid arthritis (10 cases) was made on clinical features, negative tests for rheumatoid factor, and the absence of radiological changes. Patients with osteoarthritis were excluded and no patient in the series had psoriatic or gouty arthritis.

Only patients with symptomatic ankylosing spondylitis have been included. In addition to clinical complaints of backache the diagnostic criteria were radiological, the minimal changes acceptable being bilateral loss of definition or irregularity of the sacroiliac joint spaces with subchondral sclerosis. The diagnosis of ankylosing spondylitis in patients included in this series has been made throughout by one radiologist, thus minimizing any observer variation in the diagnosis of this condition. In the majority of patients intervertebral joints were also involved. Patients with mild and moderate but asymptomatic sacroileitis have been excluded from this series.

A definite statement as to whether clubbing was present or not was made in all but three of the 399 case notes. We have accepted a definite statement of the presence of finger clubbing as the criterion for inclusion in the study, believing that the large observer variation in the recognition of this feature is obviated to some extent by the fact that the recorded observations were almost always those of two senior clinicians. No patient in this series had the syndrome of hypertrophic pulmonary osteoarthropathy.

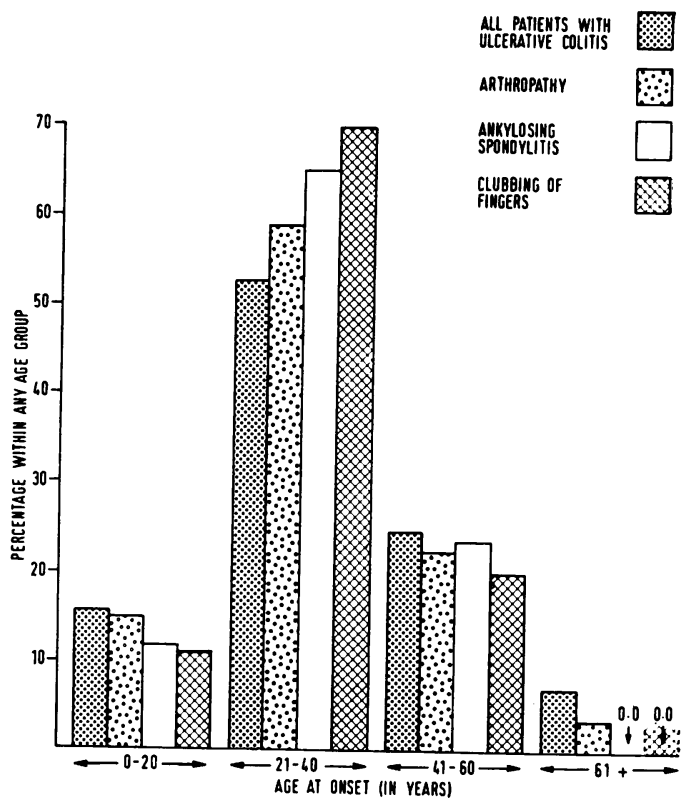

Fig. 1 Age at the onset of ulcerative colitis in patients with arthropathy, ankylosing spondylitis, and clubbing of fingers.

On these criteria, $27(6.8 \%)$ out of the total of 399 patients had arthropathy, $17(4.2 \%)$ patients had clinical ankylosing spondylitis, and $20(5 \%)$ had clubbing of the fingers.

\section{Results}

\section{ARTHRITIS}

No significant difference could be shown in the incidence of arthritis between males and females (males $6 \%$, females $7 \%$ ). The peak incidence of arthritis in the third and fourth decade coincides with the peak incidence of ulcerative colitis in the general population. No significant difference between the age groups could be shown (Fig. 1).

It was suggested by Wright and Watkinson (1965) that the incidence of colitic arthritis was related to the length of disease but no such influence was shown in this series. More patients appeared to have arthritis during a relapse of the disease but this failed to reach statistical significance at the $5 \%$ level. As well as random fluctuation the high incidence of arthritic patients in the relapse group may represent a different system of referral for these patients (Table I). Patients were considered to be in the first attack of the disease if they presented within six months of the onset of symptoms. Whether the patient developed an attack suddenly (symptoms reaching their peak within one month of the onset of 


\begin{tabular}{|c|c|c|c|c|}
\hline $\begin{array}{l}\text { State of } \\
\text { Attack }\end{array}$ & Arthropathy & $\begin{array}{l}\text { Ankylosing } \\
\text { Spondylitis }\end{array}$ & $\begin{array}{l}\text { Clubbing of } \\
\text { Fingers }\end{array}$ & Total \\
\hline $\begin{array}{l}\text { First attack } \\
\text { Relapse }\end{array}$ & $\begin{array}{r}8 \\
19\end{array}$ & $\begin{array}{l}8 \\
9\end{array}$ & $\begin{array}{r}7 \\
13\end{array}$ & $\begin{array}{l}191 \\
208\end{array}$ \\
\hline $\begin{array}{l}\text { Tests of } \\
\text { significance }\end{array}$ & $\begin{array}{l}\chi^{2}=3.12, \mathrm{df}=1, \\
0.05<\mathrm{P}<0.10\end{array}$ & $\begin{array}{l}x^{2}=0.032, \mathrm{df}=1 \\
0.80<\mathrm{P}<0.90\end{array}$ & $\begin{array}{l}x^{2}=2 \cdot 26, \text { df }=1 \\
0 \cdot 10<P<0.20\end{array}$ & \\
\hline
\end{tabular}

Table I Arthropathy, ankylosing spondylitis, and clubbing of fingers in relation to the state of attack ${ }^{1}$

${ }^{1} \mathrm{Here}$ and in Table II comparison has been made between patients with a particular complication and those without.

\begin{tabular}{llllr}
\hline $\begin{array}{l}\text { Severity of } \\
\text { Attack }\end{array}$ & Arthropathy & $\begin{array}{l}\text { Ankylosing } \\
\text { Spondylitis }\end{array}$ & $\begin{array}{l}\text { Clubbing of } \\
\text { Fingers }\end{array}$ & Total \\
\hline Mild & 11 & 9 & 4 & 180 \\
Moderate & 8 & 1 & 4 & 98 \\
Severe & 8 & 7 & 12 & 121 \\
Tests of & $x^{2}=0.43$, df $=2$, & $x^{2}=3.45$, df $=2$, & $\chi^{2}=9.24$, df $=2$, & \\
significance & $0.80<\mathrm{P}<0.90$ & $0.10<\mathrm{P}<0.20$ & $0.005<\mathrm{P}<0.01$ & \\
\hline
\end{tabular}

Table II Arthropathy, ankylosing spondylitis, and clubbing of fingers in relation to the severity of colitis

\begin{tabular}{|c|c|c|c|c|}
\hline $\begin{array}{l}\text { Extent of } \\
\text { Radiological } \\
\text { Involvement }\end{array}$ & Arthropathy & $\begin{array}{l}\text { Ankylosing } \\
\text { Spondylitis }\end{array}$ & $\begin{array}{l}\text { Clubbing of } \\
\text { Fingers }\end{array}$ & Total \\
\hline Normal $^{1}$ & 4 & 3 & 0 & 79 \\
\hline $\begin{array}{l}\text { Partial }^{2} \\
\text { and left-sided }\end{array}$ & 17 & 9 & 5 & 149 \\
\hline Entire & 6 & 3 & 12 & 131 \\
\hline Not known & 0 & 2 & 3 & 40 \\
\hline $\begin{array}{l}\text { Tests of } \\
\text { significance }\end{array}$ & $\begin{array}{l}x^{2}=5.55, \text { df }=2 \\
0.05<P<0.025\end{array}$ & $\begin{array}{l}\chi^{2}=2.49, \text { df }=2 \\
0.20<P<0.30\end{array}$ & $\begin{array}{l}x^{2}=10.24, \text { df }=2 \\
0.005<P<0.01\end{array}$ & \\
\hline
\end{tabular}

Table III Arthropathy, ankylosing spondylitis, and clubbing of fingers in relation to the extent of the involvement of the colon

${ }^{1}$ Patients with sigmoidoscopic evidence of proctitis.

${ }^{2}$ Includes patients with segmental and right-sided colitis.

attack) or gradually did not appear to have any influence on the incidence of arthritis.

The severity of colitis (Table II) was classified as mild, moderate, or severe using a scoring procedure based on temperature, number of bowel motions, and erythrocyte sedimentation rate of the patients (method to be published elsewhere). The severity of disease did not appear to have any significant effect on the incidence of arthritis.

Wright and Watkinson (1965) suggested that the incidence of colitic arthritis was related to the extent of disease but no such influence was demonstrated in this series. In our series, there were relatively more patients with arthritis who had left-sided colitis and correspondingly fewer who had extensive involvement or proctitis alone (Table III). This difference did not, however, reach a statistically significant level.

Corticosteroids produce marked symptomatic improvement in colitic arthritis. With increasing knowledge of the treatment of ulcerative colitis and the more widespread use of corticosteroids by family doctors in the first attack of the disease, it was expected that the incidence of arthritis would be decreasing. The data did not support this (results not shown).

The incidence of a family history of rheumatoid arthritis in all patients with ulcerative colitis was not found to be any higher than that expected in the general population. There was no patient in this series with a family history of collagen disease such as lupus erythematosus, scleroderma, or polyarteritis nodosa. The incidence of a family history of rheumatoid arthritis in the group of patients with colitic arthritis was also not found to be higher than expected. Fourteen patients in all gave a history of transient episodes of arthralgia before the onset of colitis. The incidence of such episodes in those with colitic arthropathy $(14.8 \%)$ was significantly higher than in the remaining colitic population $(2.8 \%)$ ( $P=0.01$ by Fisher's exact test). However, these data were based on personal recollection and there is a strong likelihood of an arthritic patient recollecting such episodes.

Wright and Watkinson (1965) pointed out the relationship between arthritis and local complications, such as pseudopolypi and perianal disease. Our results confirm their finding of a higher incidence of pseudopolypi and perianal disease in patients with arthritis (Table IV). The relationship of arthritis with other systemic manifestations of colitis, such as aphthous ulceration, skin disease, eye lesions, and liver disease has also been sought. Our results (Table IV) are again similar to those of Wright and Watkinson (1965) and show a positive association. Analysis has been carried out to look for significant differences between the sexes with regard to the above features but none could be shown.

Although arthritis causes a certain morbidity and is of interest in relation to the aetiology of ulcerative colitis, it is also important to determine how the condition modifies the outcome of an attack of colitis. In this communication outcome is judged in two ways: the immediate outcome of the first referred attack (Table V) and the status at the time of review (Table VI).

No significant differences in the short-term outcome could be shown between patients with arthritis and those without. Slightly more patients with arthritis had elective surgery, and, in a few of these patients, persistent arthropathy was the main indication. One patient had one episode of arthritis in the immediate postoperative period but no other patient has had arthritis after the removal of the large bowel.

The operative mortality and the status at the time of review were similar in both groups.

ANKYLOSING SPONDYLITIS

Out of 17 patients diagnosed as having ankylosing spondylitis, seven were males. This ratio of males to females is similar to that of the remaining 


\begin{tabular}{|c|c|c|c|}
\hline & Arthropathy & No Arthropathy & Tests of Significance \\
\hline $\begin{array}{l}\text { Perianal disease present }{ }^{1} \\
\text { Perianal disease absent }\end{array}$ & $\begin{array}{l}11 \\
16\end{array}$ & $\begin{array}{r}28 \\
344\end{array}$ & $x^{2}=27.8, \mathrm{df}=1, \mathrm{P}<0.0005$ \\
\hline $\begin{array}{l}\text { Pseudopolyposis present } \\
\text { Pseudopolyposis absent }\end{array}$ & $\begin{array}{l}13 \\
14\end{array}$ & $\begin{array}{r}62 \\
310\end{array}$ & $x^{2}=14.3, \mathrm{df}=1, \mathrm{P}<0.0005$ \\
\hline $\begin{array}{l}\text { Skin lesions present }{ }^{2} \\
\text { Skin lesions absent }\end{array}$ & $\begin{array}{l}11 \\
16\end{array}$ & $\begin{array}{r}34 \\
338\end{array}$ & $x^{2}=22 \cdot 1, \mathrm{df}=1, \mathrm{P}<0.0005$ \\
\hline $\begin{array}{l}\text { Eye lesions present }{ }^{3} \\
\text { Eye lesions absent }\end{array}$ & $\begin{array}{r}7 \\
20\end{array}$ & $\begin{array}{r}9 \\
363\end{array}$ & $x^{2}=30.4, \mathrm{df}=1, \mathrm{P}<0.0005$ \\
\hline $\begin{array}{l}\text { Aphthous ulceration present } \\
\text { Aphthous ulceration absent }\end{array}$ & $\begin{array}{l}10 \\
17\end{array}$ & $\begin{array}{r}41 \\
331\end{array}$ & $x^{2}=13.0, \mathrm{df}=1, \mathrm{P}<0.0005$ \\
\hline $\begin{array}{l}\text { Liver disease present } \\
\text { Liver disease absent }\end{array}$ & $\begin{array}{r}8 \\
19\end{array}$ & $\begin{array}{r}51 \\
321\end{array}$ & $x^{2}=3.87, \mathrm{df}=1,0.025<\mathrm{P}<0.05$ \\
\hline $\begin{array}{l}\text { Ankylosing spondylitis present } \\
\text { Ankylosing spondylitis absent }\end{array}$ & $\begin{array}{r}7 \\
20\end{array}$ & $\begin{array}{r}10 \\
362\end{array}$ & $x^{2}=27.9, \mathrm{df}=1, \mathrm{P}<0.0005$ \\
\hline
\end{tabular}

Table IV Arthropathy in relation to local and systemic complications of ulcerative colitis

${ }^{1}$ Includes patients with ischiorectal abscess, fistula in ano, and perianal abscess.

${ }^{2}$ Includes patients with erythema nodosum, pyoderma gangrenosum, and maculopopular rash.

${ }^{3}$ Includes patients with iritis, uveitis, and conjunctivitis.

"Includes patients with pericholangitis, cirrhosis of the liver, fatty infiltration, hepatitis, massive necrosis, and isolated biochemical abnormality of alkaline phosphatase or bromsulphthalein retention.

colitic population (Fig. 1) and is not like the relative preponderance of females with ankylosing spondylitis found by Wright and Watkinson (1965). The peak age incidence was similar to that of arthropathy and did not differ from the rest of the colitis population (Fig. 1).

No significant relationship between ankylosing spondylitis and mode of onset, attack state (Table I), or duration of disease (Fig. 2) could be shown.

No relation was found between the incidence of spondylitis and the extent of involvement of the colon (Table III). More patients had colitis confined to the left side of the colon. This was

\begin{tabular}{lrrrr}
\hline Outcome & Arthropathy & $\begin{array}{l}\text { Ankylosing } \\
\text { Spondylitis }\end{array}$ & $\begin{array}{l}\text { Clubbing of } \\
\text { Fingers }\end{array}$ & Total \\
\hline Remission & 15 & 11 & 5 & 263 \\
Improved & 3 & 2 & 2 & 24 \\
Surgical survivors & 8 & 3 & 11 & 79 \\
Death on medical & & 1 & 2 & 16 \\
treatment & 0 & 0 & 0 & 17 \\
Death after surgery & 1 & 17 & 20 & 399 \\
Total & 27 & & & \\
\hline
\end{tabular}

Table V Outcome of the first referred attack in patients with arthropathy, ankylosing spondylitis, and clubbing of fingers

\begin{tabular}{llllc}
\hline Status & Arthropathy & $\begin{array}{l}\text { Ankylosing } \\
\text { Spondylitis }\end{array}$ & $\begin{array}{l}\text { Clubbing of } \\
\text { Fingers }\end{array}$ & Total \\
\hline $\begin{array}{l}\text { Survivors } \\
\begin{array}{l}\text { Deaths } \\
\text { Related to medical }\end{array}\end{array}$ & 22 & 15 & 15 & 334 \\
$\begin{array}{l}\text { causes of colitis } \\
\text { Related to surgical }\end{array}$ & 2 & 1 & 2 & \\
$\quad \begin{array}{l}\text { causes cf colitis } \\
\text { Incidental }\end{array}$ & 3 & 1 & 2 & 27 \\
Total & 0 & 0 & 1 & 14 \\
\hline
\end{tabular}

Table VI Survival status at time of review in patients with arthropathy, ankylosing spondylitis, cind clubbing of fingers

${ }^{1}$ Review status not known in five patients. 


\begin{tabular}{|c|c|c|c|}
\hline Complication & Clubbing & No Clubbing & Tests of Significance \\
\hline $\begin{array}{l}\text { Ankylosing spondylitis present } \\
\text { Ankylosing spondylitis absent }\end{array}$ & $\begin{array}{r}4 \\
16\end{array}$ & $\begin{array}{r}13 \\
358\end{array}$ & $P=0.008$ (exact test) \\
\hline $\begin{array}{l}\text { Ulcerative colitis, arthropathy present } \\
\text { Ulcerative colitis, arthropathy absent }\end{array}$ & $\begin{array}{r}3 \\
17\end{array}$ & $\begin{array}{r}24 \\
355\end{array}$ & $P=0.145($ exact test $)$ \\
\hline $\begin{array}{l}\text { Carcinoma present } \\
\text { Carcinoma absent }\end{array}$ & $\begin{array}{r}3 \\
17\end{array}$ & $\begin{array}{r}6 \\
373\end{array}$ & $P=0.007$ (exact test) \\
\hline $\begin{array}{l}\text { Pseudopolyposis present } \\
\text { Pseudopolyposis absent }\end{array}$ & $\begin{array}{r}8 \\
12\end{array}$ & $\begin{array}{r}67 \\
312\end{array}$ & $x^{2}=4.82, \mathrm{df}=1,0.025<\mathrm{P}<0.05$ \\
\hline $\begin{array}{l}\text { Toxic dilatation present } \\
\text { Toxic dilatation absent }\end{array}$ & $\begin{array}{r}6 \\
14\end{array}$ & $\begin{array}{r}49 \\
330\end{array}$ & $\chi^{2}=3.33, \mathrm{df}=1,0.05<P<0.1$ \\
\hline $\begin{array}{l}\text { Liver disease present } \\
\text { Liver disease absent }\end{array}$ & $\begin{array}{r}4 \\
16\end{array}$ & $\begin{array}{r}55 \\
324\end{array}$ & $x^{2}=0.123, \mathrm{df}=1,0.70<P<0.80$ \\
\hline $\begin{array}{l}\text { Skin disease present } \\
\text { Skin disease absent }\end{array}$ & $\begin{array}{r}4 \\
16\end{array}$ & $\begin{array}{r}41 \\
338\end{array}$ & $x^{2}=0.815, \mathrm{df}=1,0.30<\mathrm{P}<0.40$ \\
\hline $\begin{array}{l}\text { Eye lesions present } \\
\text { Eye lesions absent }\end{array}$ & $\begin{array}{r}1 \\
19\end{array}$ & $\begin{array}{r}15 \\
364\end{array}$ & $P=0.4($ exact test $)$ \\
\hline
\end{tabular}

Table VIII Clubbing of fingers in relation to local and systemic complications of ulcerative colitis

\begin{tabular}{|c|c|c|c|}
\hline Complication & $\begin{array}{l}\text { Ankylosing } \\
\text { Spondylitis }\end{array}$ & $\begin{array}{l}\text { No Ankylosing } \\
\text { Spondylitis }\end{array}$ & Tests of Significance \\
\hline $\begin{array}{l}\text { Perianal disease present } \\
\text { Perianal disease absent }\end{array}$ & $\begin{array}{l}1 \mathrm{man}, 7 \text { women } \\
6 \mathrm{men}, 3 \text { women }\end{array}$ & $\begin{array}{r}13 \text { men, } 18 \text { women } \\
153 \text { men, } 198 \text { women }\end{array}$ & $\begin{array}{l}\text { For men: } P=0.45 \text { (exact test) and for } \\
\text { women: } P=0.00003 \text { (exact test) }\end{array}$ \\
\hline $\begin{array}{l}\text { Pseudopolyposis present } \\
\text { Pseudopolyposis absent }\end{array}$ & $\begin{array}{r}6 \\
11\end{array}$ & $\begin{array}{r}69 \\
313\end{array}$ & $\chi^{2}=2.13$, df $=1,0.1<P<0.2$ \\
\hline $\begin{array}{l}\text { Eye lesion present } \\
\text { Eye lesion absent }\end{array}$ & $\begin{array}{r}3 \\
14\end{array}$ & $\begin{array}{r}13 \\
369\end{array}$ & $P=0.026($ exact test $)$ \\
\hline $\begin{array}{l}\text { Aphthous ulcration present } \\
\text { Aphthous ulceration absent }\end{array}$ & $\begin{array}{r}4 \\
13\end{array}$ & $\begin{array}{r}47 \\
335\end{array}$ & $x^{2}=0.97, \mathrm{df}=1,0.3<\mathrm{P}<0.4$ \\
\hline
\end{tabular}

Table VII Ankylosing spondylitis in relation to local and systemic complications of ulcerative colitis

also found to be true for surgically treated patients in whom the resected specimen could be examined and the true extent of disease determined. Ankylosing spondylitis does not appear to reflect severity of the colitis (Table II).

Because of the small numbers involved, it was not possible to demonstrate a relationship between spondylitis and eye lesions, but the association between local and systemic complaints of ulcerative colitis was investigated (Table VII). In the female, there was an association of perianal disease with ankylosing spondylitis. A significant association was also present between ankylosing spondylitis and colitic arthritis. Seven patients had both of these conditions. The characteristics of these seven patients did not differ in any respect from patients in either of the individual categories.

It is seen that the presence of ankylosing spondylitis has no apparent influence on the overall outcome (Table V). In none of the patients who had surgery was the clinical or radiological course of ankylosing spondylitis modified by proctocolectomy (Table VI).

\section{CLUBBING OF FINGERS}

Clubbing was present in $20(5 \%)$ of the 399 patients. The sex incidence was equal. The incidence of clubbing increases with age (Fig. 1). Out of the 116 patients who were aged less than 30 at the onset of colitis there are only two with clubbing. The age distribution of the remaining 18 followed the age distribution of the rest of the colitic population above 30 years of age.

The frequency of clubbing is correlated with the length of history of the colitis $(P=0.026$, by the Wilcoxon test) (Fig. 2). No relationship could be shown to the attack state or to the mode of onset (Table I). But a positive association appears between clubbing and the degree of severity of colitis (Table II). A significant relationship exists between extensive involvement of large bowel and clubbing (Table III). This was confirmed in those situations where the true extent of disease could be determined by examination of the resected specimen. In one patient the involvement was limited to the left side.

A positive association exists between clubbing of fingers and other complications of ulcerative colitis, including toxic dilatation, pseudopolyposis, arthropathy, and ankylosing spondylitis (Table VIII). No relationship could be shown with liver disease. A significant relationship could also be shown between complicating carcinoma of the colon and clubbing. Of 399 patients, nine had carcinoma and three of these had clubbing of the fingers. 
Although the majority of patients with clubbing ultimately required surgical treatment, the mortality is not significantly different from the expected and the outcome of first referred attack was not altered (Table V). At the time of review a slightly higher number of deaths than expected had occurred in patients with clubbing (Table VI). It should be noted that these deaths include the three patients who had carcinoma of the colon.

\section{Discussion}

A transient and asymmetrical monoarticular arthropathy in a patient with ulcerative colitis suggests a diagnosis of colitic arthritis as opposed to one of rheumatoid arthritis. Subcutaneous nodules, muscle wasting, and tendon-sheath effusions do not occur. Serological tests for rheumatoid factor which are commonly positive in rheumatoid arthritis are negative. The small erosions described as the residual changes of colitic arthritis (Bywaters and Ansell, 1958) are rare and have not been observed in this series.

The reported incidence of colitic arthritis has varied upward from $2.22 \%$ (Hamilton, 1957; Fischel, 1949). Our own retrospectively determined incidence of $6.8 \%$ is to be compared with that of $11.5 \%$ found by Wright and Watkinson (1965) in a prospective study of 269 subjects in which $45 \%$ of their patients had some 'rheumatic' complaint.

In our series symptoms of arthritis antedated the onset of colitis in four out of 27 patients similar to the incidence of 10 to $19 \%$ reported by others (Bywaters and Ansell, 1958; Fernandez-Herlikey, 1959; Ford and Vallis, 1959; McEwen et al, 1962). This may lend support to the contention of Burch, de Dombal, and Watkinson (1959) that there is a latent period in ulcerative colitis before the alimentary manifestations of the disease become apparent. The overall outcome of ulcerative colitis seems to be largely independent of the presence of arthritis. Our own experience supports the view that recurrence of arthritic symptoms is rare after surgery (Brooke, 1954 and 1956; Wright and Watkinson, 1965). It is also our experience that the arthritis is transient and may remit for long periods. The presence of arthritis should not unduly influence a decision regarding surgery in the management of ulcerative colitis.

Rotstein, Entel, and Zeviner (1963) showed an association between colitic arthritis and ankylosing spondylitis and suggested that the arthritis might be a manifestation of the spondylitis. We have also found this association. Furthermore, many patients without ulcerative colitis who have ankylosing spondylitis and who develop a peripheral arthropathy have only transient involvement of peripheral joints. This study has also shown that there is no significant difference in the clinical and anatomical features of ulcerative colitis in patients with ankylosing spondylitis or colitic arthritis and of those without these complications. The relation of colitic arthritis to continuing disease of the large bowel on the one hand and the failure of ankylosing spondylitis to regress after proctocolectomy on the other seem to suggest that spondylitis and arthritis represent different disease processes. It seems unreasonable, however, to propose two disease processes involving structures of related morphology since it is possible that functional differences between central and peripheral joints explain the differences in the behaviour of these joints after proctocolectomy. On the data so far available, this question cannot be resolved.

It has been suggested that colitic arthritis and ankylosing spondylitis may be part of a generalized disease process. The dependence of the arthritis on continuing activity of ulcerative colitis is against this. It has been held that these systemic complications represent a hypersensitivity reaction to antigens common to bowel and joints. Perhaps both processes are present but at the present time the causation of joint disease in ulcerative colitis is unknown.

A positive association is shown between finger clubbing and extensive involvement of the colon and also with severe disease. The incidence of clubbing in our patients $(5 \%)$ is similar to that found by Young (1966). The association of clubbing with severe disease is emphasized by the relationship we also found with toxic dilatation and pseudopolyposis. The high incidence of carcinoma of the colon in the patients with clubbing was unexpected. The presence of clubbing in colitis should therefore alert the clinician to the exclusion of carcinoma. Clubbing tends to occur in those patients with extensive involvement and a long history and it is this group of patients who are at risk for neoplasia. In two out of the three patients who had carcinoma of the colon and clubbing of fingers carcinoma was not suspected before the operation. On the other hand, of six colitis patients with carcinoma but without clubbing, in only two was malignancy not suspected on first referral. Sixteen of the patients with clubbing required surgery. The overall mortality in our series of patients was no higher than expected. As most of the patients with clubbing underwent surgery and therefore the risk of subsequent carcinoma was removed, the possibility exists that clubbing is another indicator of the liability for the development of carcinoma of colon. The aetiology of clubbing is not known, although the vagus nerve has been thought to play a role. Support for this was provided by Young (1966) who found that none of the patients with left-sided colitis had clubbing of fingers, but in our series of patients with left-sided colitis clubbing occurred, and the relationship of clubbing to the severity of the 
colitis indicates that factors other than intact vagal innervation must be present. In a patient recently studied and not included in this series, finger clubbing was seen to develop during a severe attack of colitis despite the fact that she was known to have had a complete truncal vagotomy for duodenal ulceration.

The association between these three and other complications of ulcerative colitis points to a common aetiological mechanism. The presence of one increases the probability of observing others in the same patient but the eventual outcome appears to be uninfluenced.

We wish to thank Mrs L. Lockerbie, Mrs J. Herson, and the staff of the Computer and Statistics Section of the Department of Social Medicine, University of Edinburgh, for valuable technical assistance, $\mathrm{Mr} \mathrm{C}$. W. A. Falconer, Mr W. P. Small, and Mr A. N. Smith for allowing us to study patients under our joint care, and Dr D. H. Cummack for helpful criticisms.

Dr K. N. Jalan was supported for this work initially by the Scottish Hospitals Endowment Research Trust and latterly by Pharmacia (Great Britain) Ltd, during the tenure of a research fellowship.

\section{Referen :es}

Acheson, E. D. (1960). An association between ulcerative colitis, regional enteritis and ankylosing spondylitis. Quart. $J$. Med., 29, 489-499.

Bargen, J. A. (1929). Complications and sequelae of chronic ulcerative colitis. Ann. intern. Med., 3, 335-352.
Brooke, B. N. (1954). Results including mortality, rehabilitation, nutrition and pregnancy. In Ulcerative Colitis and its Surgical Treatment. Livingstone, Edinburgh.

Burch, P. R. J., De Dombal, F. T., and Watkinson, G. (1969), Aetiology of ulcerative colitis. 2. A new hypothesis. Gut, 10, $277-284$.

Bywaters, E. G. L., and Ansell, B. M. (1958). Arthritis associated with ulcerative colitis: A clinical and pathological study. Ann. rheum. Dis., 17, 169-183.

Fernandez-Herlihy, L. (1959). The articular manifestations of chronic ulcerative colitis: An analysis of 555 cases. New Engl. J. Med., 261, 259-263.

Fischel, E. E. (1949). Ulcerative colitis. Amer. J. Med., 6, 485-486. 을

Ford, D. K., and Vallis, D. G. (1959). The clinical course of arthritis associated with ulcerative colitis and regional ileitis. Arthr. and Rheum., 2, 526-536.

Hamilton, N. T. (1957). A Review of ulcerative colitis at the Alfred Hospital, 1945-55. Alfred Hosp. clin. Rep. (Melbourne), 7, 15-29.

Hench, P. S., Bauer, W., Boland, E., Dawson, M. H., Freyberg, R. H., Holbrook, W. P., Key, J. A., Lockie, L. M., and McEwen, C. (1941). Rheumatism and arthritis: A review of American and English literature for 1940. Ann. intern. Med., 15, 1002-1108.

Honska, W. L., Strenge, H., and Hammarsten, J. F. (1957). Hypertrophic osteoarthropathy and chronic ulcerative colitis. Gastroenterology, 33, 489-492.

Jalan, K. N., Prescott, R. J., Sircus, W., Card, W. I., McManus, J. P. A., Falconer, C. W. A., Small, W. P., and Smith, A. N. (1970). An experience of ulcerative colitis: II-A clinical study of 399 patients. Gastroenterology. (In Press.)

McBride, J. A., King, M. J., Baikie, A. G., Crean, G. P., and Sircus, W. (1963). Ankylosing spondylitis and chronic inflammatory diseases of the intestines. Brit. med. J., 2, 483-486.

McEwan, C., Lingg, C., Kirsner, J. B., and Spencer, J. A. (1962). Arthritis accompanying ulcerative colitis. Amer. J. Med., 33, 923-941.

Mendlowitz, M. (1941). Measurements of blood flow and pressure in clubbed fingers. J. clin. Invest., 20, 113-117.

Rotstein, J., Entel, I., and Zeviner, B. (1963). Arthritis associated with ulcerative colitis. Ann, rheum. Dis, 22, 194-197.

Schlicke, C. P., and Bargen, J. A. (1940). 'Clubbed fingers' and ulcerative colitis. Amer. J. dig. Dis., 7, 17-21.

Wright, V., and Watkinson, G. (1959). The arthritis of ulcerative colitis. Medicine (Baltimore), 38, 243-262.

Wright, V., and Watkinson, G. (1965). The arthritis of ulcerative colitis. Brit. med. J., 2, 670-675.

Young, J. R. (1966). Ulcerative colitis and finger clubbing. Brit. med. J., 1, 278-279. 